\title{
Evaluation of Improved Food Barley (Hordeum vulgare L.) Varieties in the Highland Areas of Kaffa Zone, Southwestern Ethiopia
}

\author{
Teshome Mamo Maggo ${ }^{1,2}$ \\ ${ }^{1}$ Southern Agricultural Research Institute (SARI), Crop Research Directorate, Hawassa, Ethiopia \\ ${ }^{2}$ Bonga Agricultural Research Centre, Bonga, Ethiopia
}

Email address:

tesheden@gmail.com

\section{To cite this article:}

Teshome Mamo Maggo. Evaluation of Improved Food Barley (Hordeum vulgare L.) Varieties in the Highland Areas of Kaffa Zone, Southwestern Ethiopia. Agriculture, Forestry and Fisheries. Vol. 6, No. 5, 2017, pp. 161-165. doi: 10.11648/j.aff.20170605.13

Received: March 1, 2017; Accepted: May 3, 2017; Published: September 5, 2017

\begin{abstract}
The field experiment was conducted at Alarigata testing site of Bonga Agricultural Research Center in the 2012 and 2013 cropping season using ten improved food barley (Hordeum vulgare L.) varieties with the local check. The improved varieties studied include Biftu, Dafo, Abdane, Dimtu, HB-1307, Ardu-1260B, Shege, Dinsho, HB-42 and Diribe. These varieties, as experimental treatments, were arranged in a randomized complete block design with three replications. They were evaluated for days to $50 \%$ heading, days to $95 \%$ physiological maturity, plant height, grain yield, thousand kernel weights, lodging, shattering, and incidence of disease and insects. Farmers' assessment was also made on the performance of the test varieties at flowering and physiological maturity stages. Significant variations were recorded among the tested varieties in the measured traits. However, no considerable amounts of lodging, shattering, incidence of disease and insects were observed on the tested varieties during the study periods. The highest average grain yield (4.6 tons ha $\left.{ }^{-1}\right)$ was obtained from variety Diribe followed by HB-42 $\left(3.5\right.$ tons ha $\left.{ }^{-1}\right)$. The result obtained from variety Diribe coincided with the perception of farmers in the study area. Based on the results obtained under this study variety Diribe could be used for demonstration, popularization and pre-scaling up in Alarigata and in the farming communities of similar agro-ecologies.
\end{abstract}

Keywords: Food Barley, Variety, Days to Heading, Physiological Maturity, Plant Height, Grain Yield, Thousand Kernel Weight

\section{Introduction}

Barley (Hordeum vulgare L.) is a major cereal crop in Ethiopia and accounts for $8 \%$ of the total cereal production [11]. It is grown in a wide range of agro climatic regions under several production systems. Barley grows best on welldrained soils and can tolerate higher levels of soil salinity than most other crops. Food barley is commonly cultivated in stressed areas where soil erosion, occasional drought or frost limits the ability to grow other crops [2]. Barley has persisted as a major cereal crop through many centuries and it is the world's fourth important cereal crop after wheat, maize and rice [7]. Barley has a long history of cultivation in Ethiopia as one of the major cereal crops and it is reported to have coincided with the beginning of plow culture [10]. It is the most important crop with total area coverage of $944,401.34$ hectares and total annual production of about 1.85 million tons in the main season [4]. Barley is also a principal Belg season crop second to maize in area coverage and production $[2,5]$. In the highlands of the country barley is grown in Oromia, Amhara, Tigray and part of the Southern Nations, Nationalities and Peoples' Regional State (SNNPR) in the altitude ranges of 1500 and $3500 \mathrm{~m}$, but it is predominantly cultivated between 2000 and 3000 masl [1, 9]. In Ethiopia, barely is a dependable source of food in the highlands as it is produced during the main and short rainy seasons as well as under residual moisture [8]. Barley types are predominantly categorized as food and malting barley based on their uses, while in Ethiopia the highest proportion of barley production area is allocated for food barley. Food barley is principally 
cultivated in the highland areas of Ethiopia where the highest consumption is in the form of various traditional foods and local beverages from different barley types [12]. Barley grain accounts for over $60 \%$ of food for the highlands of Ethiopia, for which it is the main source of calories [3]. According to [2] barley is used in diversity of recipes and deep rooted in the culture of people's diets. Besides its grain value, barley straw is an indispensable component of animal feed especially during the dry season in the highlands where feed shortage is prevalent [6]. Barley straw is also used in the construction of traditional huts and grain stores as thatching or as a mud plaster, as well as for use as bedding in the rural areas [12].

Although Ethiopia is a centre of diversity for barley, most of the farmers in the country still obtain very low yields due to a combination of genetic, environmental and socioeconomic constraints. Research has been on-going since 1955 to address these constraints and improve the livelihoods of farmers by increasing the production and productivity of barley [10].

Kaffa zone is found in the Southern Nations, Nationalities and Peoples' Regional State. It is among some of the places in the region where food barley is grown as one of the major cereal food crops of highland agro ecology. About 77,009 farmers of the zone produce food barley on 13,065.97 hectares of land [4]. However, their average productivity is only 1.41 ton per hectare [4] because the existing cultivation is not supported with new and better technologies such as high yielding and adaptive varieties with improved cultivation practices. Therefore, this study was initiated with the objective of selecting the best adaptive food barley varieties to the area.

\section{Materials and Methods}

\subsection{Description of the Study Area}

The experiment was conducted at Alarigata sub-testing site of Bonga Agricultural Research Center during 2012 and 2013 main cropping season. Alarigata is found in Adiyo district of Kaffa zone and located $491 \mathrm{~km}$ southwest of Addis Ababa which is $21 \mathrm{~km}$ away from Bonga town. The site is located at $07^{\circ} 17^{\prime} \mathrm{N}$ Latitude and $36^{\circ} 21^{\prime} \mathrm{E}$ Longitude at an altitude of 2476 meters above sea level. The area experiences one long rainy season lasting from March to November. The mean annual rainfall of the area varies from $1933 \mathrm{~mm}$ to $2543 \mathrm{~mm}$ with the mean minimum and maximum daily temperature ranging from $11.77^{\circ} \mathrm{C}$ to $26.52^{\circ} \mathrm{C}$.

\subsection{Experimental Treatments and Design}

Ten improved varieties of food barley with the local check of the respective sub-testing location were evaluated as experimental treatments. These varieties include Biftu, Dafo, Abdane, Dimtu, HB-1307, Ardu-1260B, Shege, Dinsho, HB42 and Diribe. These were randomly assigned to the experimental block and the experiment was laid out in a Randomized Complete Block Design with three replications. The spacing between blocks and plots was $1.5 \mathrm{~m}$ and $1 \mathrm{~m}$, respectively. The gross size of each plot was $3 \mathrm{~m}^{2}(1.2 \mathrm{~m} \mathrm{x}$ $2.5 \mathrm{~m}$ ) having six rows with a row-to-row spacing of $20 \mathrm{~cm}$. Two external rows from both sides of each plot were considered as border making each net plot area $2 \mathrm{~m}^{2}(0.8 \mathrm{~m} \mathrm{x}$ $2.5 \mathrm{~m})$. The total area of the experimental field was $340.2 \mathrm{~m}^{2}$ $(25.2 \mathrm{~m} X 13.5 \mathrm{~m})$. Planting was done by drilling seeds in rows with a seed rate of $100 \mathrm{~kg} \mathrm{ha}^{-1}(30 \mathrm{~g}$ per plot). DAP fertilizer was applied at the rate of $100 \mathrm{~kg} \mathrm{ha}^{-1}$ (30g per plot) at the time of planting; and Urea was also applied in two splits: at vegetative stage and before booting at the rate of 50 $\mathrm{kg} \mathrm{ha}^{-1}$ (15g per plot).

\subsection{Data Collection}

Days to $50 \%$ heading, days to $95 \%$ physiological maturity, plant height, grain yield, and thousand kernel weights were used as experimental parameters of this study. Five plants from the four internal rows of each plot were randomly tagged and the relevant data were recorded. The agronomic practices recommended for barley production were undertaken throughout the phenological stages of the crop. All plants from the four internal rows of each plot were subjected to yield evaluation.

\subsection{Data Analysis}

The analysis of variance was done using statistical analysis system, SAS 9.1 software (SAS, 2007). Mean separation was made and used with Least Significant Difference (LSD) for the comparison among the experimental varieties at $5 \%$ probability level.

\section{Results and Discussions}

\subsection{Days to $50 \%$ Heading (DH)}

The experimental varieties evaluated in the 2012 and 2013 main cropping season showed significant $(\mathrm{P}<0.05)$ differences in days to $50 \%$ heading. In the year 2012 (Table 1), variety $\mathrm{Hb}-42$ took the longest duration (77.7 days) to head, while the shortest days were recorded for Dinsho and Diribe (58.0 and 58.3 days, respectively). On the contrary, Diribe took the longest duration (85.0 days) to head in the year 2013 (Table 2), whereas Dafo, Biftu, Dinsho, Abdane and the local check took the shortest days $(57.7,59.0,59.0$, 60.7 and 61.0 days). However, the result of the averaged data of the two years (Table 3) revealed that Hb-42, Dimtu and Ardu-1260B took statistically similar longest duration (77.3, 75.3 and 74.7 days, respectively), unlike the shortest days exhibited by Dinsho (58.5 days) and Dafo (59.0 days). It was similarly reported that genotypes differ in days to $50 \%$ heading [11]. 
Table 1. Mean values of the measured parameters of food barley varieties tested in 2012 at Alarigata sub-testing site of Bonga Agricultural Research Centre, Southwestern Ethiopia.

\begin{tabular}{|c|c|c|c|c|c|c|}
\hline \multirow{2}{*}{$\mathbf{S} / \mathbf{N}$} & \multirow{2}{*}{ Var } & \multicolumn{5}{|c|}{ Mean values } \\
\hline & & DH & DM & PH & GY & TKW \\
\hline 1 & Biftu & $64.7^{\mathrm{d}}$ & $115.0^{\mathrm{d}}$ & $124.5^{\mathrm{ab}}$ & $3.2^{\mathrm{bc}}$ & $38.8^{\mathrm{cd}}$ \\
\hline 2 & Dafo & $60.3^{\mathrm{e}}$ & $112.0^{\mathrm{d}}$ & $106.7^{\text {ef }}$ & $2.9^{\text {cde }}$ & $34.9^{\mathrm{cd}}$ \\
\hline 3 & Abdane & $61.3^{\mathrm{e}}$ & $112.0^{\mathrm{d}}$ & $117.7^{\mathrm{bcd}}$ & $3.1^{\mathrm{bcd}}$ & $33.8^{\mathrm{de}}$ \\
\hline 4 & Dimtu & $75.0^{\mathrm{bc}}$ & $124.7^{\mathrm{c}}$ & $130.2^{\mathrm{a}}$ & $2.9^{\text {cde }}$ & $37.2^{\mathrm{cd}}$ \\
\hline 5 & HB-1307 & $73.7^{\mathrm{c}}$ & $137.3^{\mathrm{a}}$ & $110.3^{\text {cdef }}$ & $3.6^{\mathrm{b}}$ & $46.9^{\mathrm{ab}}$ \\
\hline 6 & Ardu-1260B & $76.3^{\mathrm{ab}}$ & $128.0^{\mathrm{b}}$ & $114.2^{\text {bcde }}$ & $2.3^{\mathrm{e}}$ & $33.6^{\mathrm{de}}$ \\
\hline 7 & Shege & $73.3^{\mathrm{c}}$ & $127.3^{\mathrm{bc}}$ & $107.5^{\mathrm{def}}$ & $3.0^{\text {bcde }}$ & $40.9^{\mathrm{bc}}$ \\
\hline 8 & Dinsho & $58.0^{\mathrm{f}}$ & $101.0^{\mathrm{e}}$ & $119.5^{\mathrm{abc}}$ & $2.8^{\text {cde }}$ & $35.2^{\mathrm{cd}}$ \\
\hline 9 & $\mathrm{Hb}-42$ & $77.7^{\mathrm{a}}$ & $138.0^{\mathrm{a}}$ & $116.4^{\text {bcde }}$ & $3.7^{\mathrm{b}}$ & $49.7^{\mathrm{a}}$ \\
\hline 10 & Diribe & $58.3^{\mathrm{f}}$ & $126.0^{\mathrm{bc}}$ & $101.0^{\mathrm{f}}$ & $4.7^{\mathrm{a}}$ & $48.3^{\mathrm{a}}$ \\
\hline 11 & Local check & $64.7^{\mathrm{d}}$ & $114.0^{\mathrm{d}}$ & $114.5^{\text {bcde }}$ & $2.3^{\mathrm{e}}$ & $28.6^{\mathrm{e}}$ \\
\hline Mean & & 67.6 & 121.4 & 114.8 & 3.1 & 38.9 \\
\hline LSD & & 1.7 & 3.1 & 11.0 & 0.8 & 6.1 \\
\hline CV (\%) & & 1.5 & 1.5 & 5.7 & 15.4 & 9.2 \\
\hline
\end{tabular}

Var= variety, $\mathrm{DH}=$ days to $50 \%$ heading, $\mathrm{DM}=$ days to $95 \%$ physiological maturity, $\mathrm{PH}=$ plant height, $\mathrm{GY}=$ grain yield, $\mathrm{TKW}=1000 \mathrm{kernel}$ weight; $\mathrm{Mean}$ values within a column followed by the same letter (s) are not significantly different at $5 \%$ level of probability

\subsection{Days to 95\% Physiological Maturity (DM)}

Statistically significant variation $(\mathrm{P}<0.05)$ was observed in days to $95 \%$ physiological maturity of the tested varieties. In the 2012 cropping season the longest duration was recorded for maturity in Hb-42 (138.0) and HB-1307 (137.3 days), whereas Dinsho took the shortest days to mature (101.0). Similarly, in the year 2013 variety HB-42 showed the longest duration (150.3 days) to mature unlike the shortest days (123 days) recorded for Biftu, Dafo, Abdane, Dinsho and the local check. The averaged mean value of days to $95 \%$ physiological maturity of the years 2012 and 2013 was longest for Hb-42 (144.2 days) and shortest for Dinsho (112.0 days). Similar study report also revealed that varieties showed significant difference in days to maturity [8].

\subsection{Plant Height (PH)}

The analysis of variance showed that there was significant $(\mathrm{P}<0.05)$ difference among the tested varieties in plant height. In the year 2012 the tallest plant height was recorded by Dimtu $(130.2 \mathrm{~cm})$, while Diribe was the shortest $(101.0 \mathrm{~cm})$. In the year $2013 \mathrm{Hb}-42$ and Dimtu showed the highest record in plant height $(122.5$ and $121.5 \mathrm{~cm}$, respectively), whereas Diribe was the shortest $(90.1 \mathrm{~cm})$. The mean value for the averaged data (Table 3 ) indicated that the highest plant height was recorded by Dimtu $(125.8 \mathrm{~cm})$ and the shortest by Diribe $(95.6 \mathrm{~cm})$.

\subsection{Grain Yield (GY)}

Statistically significant $(P<0.05)$ variation was observed among the experimental varieties in grain yield in the two cropping years (Table 1 and 2). The highest grain yield (4.7 tons $\mathrm{ha}^{-1}$ ) was obtained from variety Diribe in 2012 (Table 1) followed by Hb-42 (3.7 tons ha $\left.{ }^{-1}\right)$ but Ardu-1260B and the local check gave the lowest grain yield $\left(2.3\right.$ tons ha $\left.{ }^{-1}\right)$. Similarly, in 2013 (Table 2) Diribe was the highest yielder $\left(4.6\right.$ tons $\left.\mathrm{ha}^{-1}\right)$, while Ardu-1260B was the lowest yielder (1.8 tons $\left.\mathrm{ha}^{-1}\right)$. The highest mean value from the averaged grain yield (Table 3) was also obtained from Diribe (4.6 tons $\mathrm{ha}^{-1}$ ) followed by HB-42 (3.5 tons ha $\left.{ }^{-1}\right)$ unlike the lowest average recorded for Ardu-1260B (2.1 tons ha $\left.{ }^{-1}\right)$. This result is supported by the finding of the same study which reported that genotypes differ in grain yield [11].

Table 2. Mean values of the measured parameters of food barley varieties tested in 2013 at Alarigata sub-testing site of Bonga Agricultural Research Centre, Southwestern Ethiopia.

\begin{tabular}{lllllll}
\hline \multirow{2}{*}{ S/N } & \multirow{2}{*}{ Var } & \multicolumn{7}{l}{ Mean values } & & \\
\cline { 3 - 7 } & & DH & DM & PH & GY & TKW \\
\hline 1 & Biftu & $59.0^{\mathrm{e}}$ & $123.0^{\mathrm{d}}$ & $119.1^{\mathrm{ab}}$ & $3.2^{\mathrm{b}}$ & $39.1^{\mathrm{b}}$ \\
2 & Dafo & $57.7^{\mathrm{e}}$ & $123.0^{\mathrm{d}}$ & $115.6^{\mathrm{abc}}$ & $3.1^{\mathrm{bc}}$ & $34.5^{\mathrm{bc}}$ \\
3 & Abdane & $61.0^{\mathrm{e}}$ & $123.0^{\mathrm{d}}$ & $116.6^{\mathrm{abc}}$ & $3.5^{\mathrm{b}}$ & $31.8^{\mathrm{cd}}$ \\
4 & Dimtu & $75.67^{\mathrm{b}}$ & $134.0^{\mathrm{c}}$ & $121.5^{\mathrm{a}}$ & $3.1^{\mathrm{bc}}$ & $38.9^{\mathrm{b}}$ \\
5 & HB-1307 & $66.3^{\mathrm{d}}$ & $138.0^{\mathrm{bc}}$ & $110.9^{\mathrm{bc}}$ & $2.8^{\mathrm{bc}}$ & $35.9^{\mathrm{bc}}$ \\
6 & Ardu-1260B & $73.0^{\mathrm{bc}}$ & $140.3^{\mathrm{b}}$ & $113.6^{\mathrm{abc}}$ & $1.8^{\mathrm{d}}$ & $26.8^{\mathrm{de}}$ \\
7 & Shege & $68.3^{\mathrm{cd}}$ & $140.7^{\mathrm{b}}$ & $108.5^{\mathrm{c}}$ & $3.4^{\mathrm{b}}$ & $34.5^{\mathrm{bc}}$ \\
8 & Dinsho & $59.0^{\mathrm{e}}$ & $123.0^{\mathrm{d}}$ & $115.5^{\mathrm{abc}}$ & $3.3^{\mathrm{b}}$ & $38.3^{\mathrm{b}}$ \\
9 & Hb-42 & $77.0^{\mathrm{b}}$ & $150.3^{\mathrm{a}}$ & $122.5^{\mathrm{a}}$ & $3.3^{\mathrm{b}}$ & $45.7^{\mathrm{a}}$ \\
10 & Diribe & $85.0^{\mathrm{a}}$ & $135.0^{\mathrm{c}}$ & $90.1^{\mathrm{d}}$ & $4.6^{\mathrm{a}}$ & $40.7^{\mathrm{ab}}$ \\
11 & Local check & $60.7^{\mathrm{e}}$ & $123.0^{\mathrm{d}}$ & $114.7^{\mathrm{abc}}$ & $2.5^{\mathrm{cd}}$ & $25.1^{\mathrm{e}}$ \\
Mean & & 67.52 & 132.12 & 113.52 & 3.15 & 35.58 \\
LSD & & 5.27 & 5.31 & 9.17 & 0.74 & 6.32 \\
CV $(\%)$ & & 4.60 & 2.37 & 4.77 & 13.85 & 10.49 \\
\hline
\end{tabular}

Var $=$ variety, $\mathrm{DH}=$ days to $50 \%$ heading, $\mathrm{DM}=$ days to $95 \%$ physiological maturity, $\mathrm{PH}=$ plant height, $\mathrm{GY}=$ grain yield, $\mathrm{TKW}=1000$ kernel weight; Mean values within a column followed by the same letter (s) are not significantly different at $5 \%$ level of probability

\subsection{Thousand Kernel Weight (TKW)}

The highest mean value of thousand kernel weights was recorded for $\mathrm{Hb}-42$ and Diribe $(49.7 \mathrm{~g}$ and $48.3 \mathrm{~g}$, respectively) in the 2012 cropping year (Table 1) unlike the lowest was observed in the local check $(28.6 \mathrm{~g})$. In the year 2013 the highest mean value of thousand kernel weight was also obtained from HB-42 (45.7g) followed by Diribe $(40.7 \mathrm{~g})$, while the local check gave the lowest value (25.1g). In the same manner the average mean value of thousand kernel weight (Table 3) was highest for HB-42 (47.7g) 
followed by Diribe (44.5g) in which the lowest value was recorded for the local check $(26.9 \mathrm{~g})$.

In addition to the phenological and agronomic traits investigated under this study the tested varieties were also evaluated for other parameters like shattering, lodging, and incidence of diseases and insects during the growth stages. However, considerable amounts of incidence for these parameters were not observed on the experimental varieties during the study periods.

Table 3. Average mean values of the measured parameters of food barley varieties tested in 2012 and 2013 at Alarigata sub-testing site of Bonga Agricultural Research Centre, Southwestern Ethiopia.

\begin{tabular}{|c|c|c|c|c|c|c|}
\hline \multirow{2}{*}{$\mathbf{S} / \mathbf{N}$} & \multirow{2}{*}{ Var } & \multicolumn{5}{|c|}{ Mean values } \\
\hline & & DH & DM & PH & GY & TKW \\
\hline 1 & Biftu & $61.8^{\mathrm{c}}$ & $119.0^{\mathrm{e}}$ & $121.8^{\mathrm{ab}}$ & $3.2^{\mathrm{bc}}$ & $38.9^{\text {cd }}$ \\
\hline 2 & Dafo & $59.0^{\mathrm{d}}$ & $117.5^{\mathrm{e}}$ & $111.1^{\mathrm{def}}$ & $2.7^{\text {cde }}$ & $34.7^{\mathrm{ef}}$ \\
\hline 3 & Abdane & $61.2^{\mathrm{cd}}$ & $117.5^{\mathrm{e}}$ & $117.2^{\text {bcde }}$ & $3.3^{\mathrm{bc}}$ & $32.8^{\mathrm{fg}}$ \\
\hline 4 & Dimtu & $75.3^{\mathrm{a}}$ & $129.3^{\mathrm{d}}$ & $125.8^{\mathrm{a}}$ & $3.0^{\mathrm{bcd}}$ & $38.1^{\text {cde }}$ \\
\hline 5 & HB-1307 & $70.0^{\mathrm{b}}$ & $137.7^{b}$ & $110.6^{\mathrm{ef}}$ & $3.2^{\mathrm{bc}}$ & $41.4^{b c}$ \\
\hline 6 & Ardu-1260B & $74.7^{\mathrm{a}}$ & $134.2^{\mathrm{bc}}$ & $113.9^{\text {cdef }}$ & $2.1^{\mathrm{e}}$ & $30.2^{\text {gh }}$ \\
\hline 7 & Shege & $70.8^{\mathrm{b}}$ & $134.0^{\mathrm{bc}}$ & $108.0^{\mathrm{f}}$ & $3.2^{\mathrm{bc}}$ & $37.7^{\mathrm{de}}$ \\
\hline 8 & Dinsho & $58.5^{\mathrm{d}}$ & $112.0^{f}$ & $117.5^{\mathrm{bcd}}$ & $3.0^{\mathrm{bc}}$ & $36.7^{\mathrm{de}}$ \\
\hline 9 & $\mathrm{Hb}-42$ & $77.3^{\mathrm{a}}$ & $144.2^{\mathrm{a}}$ & $119.5^{\mathrm{abc}}$ & $3.5^{\mathrm{b}}$ & $47.7^{\mathrm{a}}$ \\
\hline 10 & Diribe & $71.7^{\mathrm{b}}$ & $130.5^{\mathrm{cd}}$ & $95.6^{\mathrm{g}}$ & $4.6^{\mathrm{a}}$ & $44.5^{\mathrm{ab}}$ \\
\hline 11 & Local check & $62.7^{\mathrm{c}}$ & $118.5^{\mathrm{e}}$ & $114.6^{\text {cdef }}$ & $2.4^{\mathrm{de}}$ & $26.9^{\mathrm{h}}$ \\
\hline Mean & & 67.5 & 126.8 & 114.1 & 3.1 & 37.2 \\
\hline LSD & & 2.7 & 4.1 & 6.7 & 0.6 & 3.4 \\
\hline CV (\%) & & 2.4 & 1.9 & 3.5 & 12.1 & 5.4 \\
\hline
\end{tabular}

Var= variety, $\mathrm{DH}=$ days to $50 \%$ heading, $\mathrm{DM}=$ days to $95 \%$ physiological maturity, $\mathrm{PH}=$ plant height, $\mathrm{GY}=$ grain yield, $\mathrm{TKW}=1000$ kernel weight; Mean values within a column followed by the same letter (s) are not significantly different at $5 \%$ level of probability

\subsection{Farmers' Assessment}

Farmers' assessment was made during flowering and at physiological maturity stages of the varieties. Fifteen selected farmers from village of Alarigata sub-testing site were participated in the assessment of varietal performance. These farmers put their opinion based on the performance of the experimental varieties. They considered early establishment at field level, uniform appearance, reaction to diseases and occurrence of insects, stem strength and lodging resistance as criteria. Based on their own evaluation criteria they grouped Diribe, Biftu and Abdane in the first rank; Shege and HB-1307 in the second; HB-42 in the third; Dimtu, Dinsho and local check in the forth; and Dafo and Ardu-1260B in the fifth rank.

\section{Conclusions and Recommendations}

Adaptability of ten improved food barley varieties (Biftu, Dafo, Abdane, Dimtu, HB-1307, Ardu-1260B, Shege, Dinsho, HB-42 and Diribe) with regard to the local check of the testing location was evaluated at Alarigata sub-testing site of Bonga Agricultural Research Centre during 2012 and 2013 main cropping season. Days to $50 \%$ heading, days to $95 \%$ physiological maturity, plant height, grain yield and thousand kernel weights of the tested varieties were measured to investigate their variability. These varieties showed significant variations in phenological and agronomic traits. The tested varieties were also evaluated for shattering (\%), lodging (\%), and incidence of diseases and insects during the growth stages. However, considerable amounts of these parameters were not observed on the experimental varieties during the study periods. Fifteen farmers were selected from Alarigata village and made assessment on the performance of the experimental varieties during flowering and at physiological maturity stages and put their opinions. The highest average grain yield was obtained from variety Diribe (4.6 tons ha ${ }^{-1}$ ) followed by HB-42 (3.5 tons ha ${ }^{-1}$ ). The highest average mean value of thousand kernel weight was recorded by HB-42 (47.7g) followed by Diribe (44.5g). The highest average yield, freedom from shattering, lodging, and incidence of diseases and insects combined with the farmers' preference made variety Diribe ranked first and selected. Therefore, based on its phenological, pathological and agronomic performances observed from this experiment variety Diribe could be popularized and scaled up to the farming communities of the testing area and to the farmers of similar agro ecology. HB-42 could also be scaled up to the same areas based on its performance. Future research actions should also focus on the performance of the selected two varieties with regard to the rate of fertilizer application.

\section{Acknowledgements}

The author acknowledges the Southern Agricultural Research Institute and Bonga Agricultural Research Centre for financing this study and providing the facilities required. The author is also indebted to the staff of Bonga Agricultural Research Centre in general, and to Fikadu Ejigu, Tariku Teka, Andualem Gadisa and Asrat Abuye in particular, for their unreserved support in conducting the experiment.

\section{References}

[1] Berhane Lakew, Hailu Gebre and Fekadu Alemayehu. 1996. Barley production and research. Pp 1-8. In: Hailu Gebre and Joob Van Luer (eds). Barley Research in Ethiopia: Past work and future prospects. Proceedings of the first barley research review workshop 16-19, October. 1993. Addis Ababa, IAR/ICARDA. Addis Ababa, Ethiopia.

[2] Berhanu Bekele, Fekadu Alemayehu and Berhane Lakew. 2005. Food barley in Ethiopia. Pp 53-82. In: Grando, Stefania and Helena Gomez Macpherson (eds). 2005. Food Barley: Importance, uses and local knowledge. Proceedings of the international workshop on food barley improvement, 14-17. January 2002, Hammamet, Tunisia. ICARDA.

[3] Ceccarelli, SS. Grando, V. Shevostove, Vivar, H Yahyaoui, A, El-Bhoussini, M. and Baun, M. 1999. ICARDA Strategy for global barley improvement. RACHIS. 18: 3-12.

[4] CSA (Central Statistical Agency), 2016. Agricultural Sample Survey Report on Area and Production of Major Crops. (Private Peasant Holdings, Meher Season). Statistical Bulletin. Addis Ababa, Ethiopia. 
[5] CSA. (Central Statistical Agency), 2008. Agricultural Sample Survey Report on Area and Production of Major Crops. (Private Peasant Holdings, Meher Season). Statistical Bulletin. Addis Ababa, Ethiopia.

[6] Girma Getachew, Abate Tedila, Seyum Bediye and Amaha Sebsibe, 1996. Improvement and utilization of barley straw. Pp 171-181. In: Hailu Gebre and Joob Van Luer (eds). Barley Research in Ethiopia: Past work and future prospects. Proceedings of the $1^{\text {st }}$ barley research review workshop 16-19 October. 1993. Addis Ababa, IAR/ICARDA.

[7] Martin, JH Walden, RP and Stamp, DL. 2006. Principle of field crop production. Pearson Education, Inc. USA.

[8] Melle Tilahun, Asfaw Azanaw and Getachew Tilahun. 2015. Participatory evaluation and promotion of improved food barley varieties in the highlands of north western Ethiopia. Wudpecker Journal of Agricultural Research. Vol. 4(3), pp. $050-053$.
[9] MoA (Ministry of Agriculture). 1998. National Livestock Development Project (NLDP) Working Paper 1-4. Addis Ababa, Ethiopia.

[10] Mulatu, B. and Grando, S. (eds). 2011. Barley Research and Development in Ethiopia. Proceedings of the 2nd National Barley Research and Development Review Workshop. 28-30 November 2006, HARC, Holetta, Ethiopia. ICARDA, P. O Box 5466, Aleppo, Syria. pp xiv +391 .

[11] Wosene, G. Abtew, Berhane Lakew, Bettina I. G. Haussmann and Karl J. Schmid, 2015. Ethiopian barley landraces show higher yield stability and comparable yield to improved varieties in multi-environment field trials. Journals of Plant Breeding and Crop Science. Vol. 7(8), pp. 1-17.

[12] Zemede Asfaw, 2000. The Barley of Ethiopia. Pp 77-108. In: Stephen B. Brush (ed). Genes in the Field: On farm Conservation of Crop Diversity. IDRC/IPGRI. 